\title{
РЫНОЧНЫЙ ПОТЕНЦИАЛ ПРОМЫШЛЕННЫХ ТЕХНОЛОГИЙ ПОЛУЧЕНИЯ СИНТЕТИЧЕСКИХ ОСНОВ МОТОРНЫХ МАСЕЛ
}

\author{
И.А. Макарян, И.В. Седов \\ ИРЭН АРМЕНОВНА МАКАРЯН - кандидат химических наук, ведущзий научный сотрудник Института \\ проблем химической физики Российской Академии наук (ИПХФ РАН), руководитель группь конъюнктурных \\ и технико-экономических исследований.E-mail: irenmak@icp.ac.ru.
}

ИГОРЬ ВЛАДИМИРОВИЧ СЕДОВ - кандидат химических наук Института проблем химической физики Российской Академии наук (ИПХФ РАН), заведующий химико-технологическим отделом.

E-mail: isedov@icp.ac.ru.

142432, Московская обл., г. Черноголовка, проспект академика Семенова, 1. Институт проблем химической физики РАН, Черноголовка, Россия.

В обзоре проанализированы литературные данные научных, прикладных и маркетинговых исследований по созданию современных базовых синтетических основ моторных масел в качестве товарной продукции. Рассмотрены принятые в мировой практике принятые в мировой практике классификации и эксплуатационные характеристики базовых масел. Представлены основные тренды научных исследований по разработке эффективных базовых синтетических основ моторных масел и перспективы их дальнейшего развития. Дана оиенка состояния мирового и российского рынков моторных масел по основным конъюнктурным показателям; представлен прогноз развития рынков на ближайшие годы.

Ключевые слова: моторные масла, базовые основы масел, синтетические основы базовых масел, полиолефиновые масла, технология получения, конъюнктура рынка, прогноз развития рынка.

\section{MAKET POTENTIAL OF INDUSTRIAL TECHNOLOGIES FOR PRODUCTION OF SYNTHETIC BASES OF MOTOR OILS}

\section{I.A. Makaryan, I. V. Sedov}

1, Ac. Semenov Avenue, Chernogolovka, Moscow region, 142432, Russia. Institute of Problems of Chemical Physics of RAS.

The review represents the literary data on scientific, applied and market studies on development of synthetic bases of modern motor oils. The conventional world-known classifications and operational characteristics of basic oils are considered. The main trends in scientific researches on development of synthetic bases of motor oils and prospects of their evolution are presented. The state of the global and Russian markets of motor oils and market forecast are analyzed.

Keywords: motor oil, basic oil, synthetic bases of oil, polyolefin oil, technology, market state, market forecast. 


\section{Введение}

Научно-технический прогресс, интенсивное развитие техники и создание новых типов мощных двигателей, сложнейших машин и механизмов повышает требования к различным типам смазочных материалов, включая моторные масла, что способствует долговечности и надежности работы этих агрегатов, снижению коррозии металлов, уменьшению расхода топлива и токсичности выхлопных газов. Моторными маслами принято называть масла для двигателей внутреннего сгорания, которые предназначены для смазывания карбюраторных, дизельных и авиационных поршневых двигателей, а также двухтактных бензиновых двигателей.

В настоящее время наиболее распространены традиционные нефтяные (или минеральные) масла, для производства которых перерабатывается около 2 масс.\% всей добываемой в мире нефти. Однако минеральные масла на основе нефти имеют ряд существенных ограничений в применении: наличие в них парафинов может приводить к плохому смазыванию (текучести) при низкой температуре; низкая окислительная стабильность при постоянно высоких температурах (образование шламовых и кислотных осадков); зависимость вязкости от температуры (сильное разжижение при высокой и застывание при низкой температуре); в жестких условиях эксплуатации при чрезвычайно высоких температурах минеральное масло теряет свои смазывающие свойства, разлагаясь с образованием коксовых отложений [1].

Так, во многих случаях минеральные масла перестали соответствовать требованиям эксплуатации современных двигателей, машин и механизмов. Поэтому с целью повышения качества традиционных масел в противовес им стали разрабатываться, и весьма успешно, синтетические смазочные материалы. Практика показала, что синтетические масла могут эффективно применяться при температурах от -70 до $+290{ }^{\circ} \mathrm{C}$ (лучшие смазочные материалы на минеральной основе эксплуатируются при температурах от -20 до $+240{ }^{\circ} \mathrm{C}$ ), при этом срок эксплуатации синтетических смазочных масел может достигать 8000 часов, в то время как нефтяных масел этот показатель составляет 500-2000 часов. При замене нефтяных масел на синтетические обеспечивается реальная экономия горючего и сокращение расходов на масло, ремонтные услуги и утилизацию отходов. Помимо этого, замена минеральных масел на синтетические существенно улучшает экологические характеристики действия механизмов, в связи с чем темпы роста производства синтетических масел все более ускоряются.
Технологии получения смазочных масел постоянно совершенствуются, сопровождаясь разработкой целиком инновационных процессов. В настоящее время мировой рынок смазочных материалов в целом успешно развивается и оценивается в 152 млрд долларов и, согласно прогнозам, в период 2016-2021 он будет увеличиваться со скоростью 2,4 \% в год и к 2021 г. достигнет значения в 166,59 млрд долларов [2].

Положение на рынке смазочных материалов в последние годы складывается так, что может создаться впечатление некоторого снижения темпов роста их потребления. Это можно объяснить тем, что современные смазочные материалы отличаются более продолжительным сроком службы, что обеспечивает более высокие эксплуатационные характеристики смазываемого ими оборудования и приводит к снижению затрат на его ремонт и техническое обслуживание. Одной из причин снижения удельного расхода смазочных материалов и спада спроса на них может быть и неуклонно растущее удорожание технологий по утилизации и регенерации отработанных масел [3].

Целью настоящего обзора является оценка технических возможностей и коммерческого потенциала развиваемых в последнее время технологий промышленного производства базовых синтетических основ моторных масел в качестве востребованных рыночных продуктов, а также рассмотрение конъюнктурных особенностей мирового и отечественного рынков смазочных масел с перспективой их дальнейшего развития.

\section{1. Базовые основы моторных масел}

\section{1. Общуие сведения о моторных маслах и их характеристики}

Современные моторные масла представляют собой сбалансированный коллоидный раствор различных функциональных присадок в базовой минеральной (нефтяной) или синтетической основе. На базовую составляющую обычно приходится около 70-80 \% общего объема моторного масла, а на присадки - оставшиеся 20-30 \%. В то время как базовые масла обеспечивают сам процесс смазки, добавленные присадки призваны значительно улучшить эксплуатационные характеристики моторных масел [4].

В качестве базовых масел, как правило, используют дистиллятные и остаточные компоненты различной вязкости (углеводороды) из фракций сырой нефти, их смеси, углеводородные компоненты, полученные гидрокрекингом и последующей гидроизомеризацией, а также синтетические про- 
дукты (высокомолекулярные углеводороды, полиальфаолефины, сложные эфиры и др.).

Присадки делятся на три группы: модифицирующие (изменяют свойства масел), присадки для защиты механизмов и присадки для защиты самого масла. Набор присадок в виде различных модификаторов вязкости, антиоксидантов и ингибиторов коррозии обеспечивает соответствие моторных масел современным требованиям. При этом некоторые базовые масла сами изначально бывают настолько качественны, что могут самостоятельно обеспечивать эффективное смазывание деталей без добавления различных присадок и дополнительных ингредиентов. Первая коммерческая присадка к моторному маслу была выпущена в середине 1930-х годов и была детергентной; затем появились и другие виды присадок: противоокислительные, противоизносные, противозадирные, противокоррозионные и пр. Особо популярны многофункциональные присадки либо в виде смеси присадок, либо в виде сложных органических соединений, содержащих полярные функциональные группы, серу, фосфор и некоторые металлы.

В упрощенном виде производственная цепочка получения моторных масел в промышленных масштабах состоит из производителей присадок с определенным пакетом присадок и производителей различных базовых масел, продукция которых поставляется конечным производителям товарных масел, выпускающим на этой основе и поставляющим на рынок конечные моторные масла различной сортности [5].

Базовые масла принято описывать четырьмя физическими свойствами, которые определяют их основные эксплуатационные характеристики: температура застывания, вязкость, индекс вязкости VI (viscosity index) и чистота (наличие серы, азота и полициклических ароматических соединений строго ограничено). Надежность моторных масел при низких температурах характеризуют температурой застывания и кинематической вязкостью при $-40{ }^{\circ} \mathrm{C}\left(\mathrm{KV}^{-40}\right)$, а количественной характеристикой зависимости вязкости масла от температуры служит индекс вязкости VI.

Условно базовые масла для производства моторных масел подразделяют на три основных типа: минеральные, синтетические и полусинтетические. Минеральные масла отличаются тем, что все находящиеся в основе минеральных масел компоненты имеют органическое (нефтяное) происхождение, в то время как компоненты синтетических масел представляют собой вещества, полученные путем химического синтеза. Полусинтетические масла с химической точки зрения являются минеральными (содержат основу, полученную из неф- ти), но их свойства с помощью пакета присадок доводятся максимально близко к свойствам синтетических масел.

Сейчас конъюнктура мирового рынка моторных масел складывается так, что около 98 \% моторных масел до сих пор производят на минеральной основе из сырой нефти, при этом львиную долю моторных масел представляют парафиновые и нейтральные масла на основе парафинистого сырья. Статистические данные указывают на то, что приблизительно $15 \%$ мировых базовых масел являются нафтеновыми маслами, состоящими по большей части из циклических соединений, полученных из парафинистого сырья. И только 1-2 \% приходятся на синтетические масла и масла, получаемые из возобновляемого и переработанного сырья.

\section{2 Классификаччия базовых масел}

Первая классификация моторных масел была введена американским в 1911 г. Сообществом автомобильных инженеров (SAE). Она разделяла масла в зависимости от их вязкости на: зимние, обозначаемые буквой W (winter), маловязкие и применяемые зимой $(\mathrm{SAE} 0 \mathrm{~W}, 5 \mathrm{~W}, 10 \mathrm{~W}, 15 \mathrm{~W}, 20 \mathrm{~W}, 25 \mathrm{~W})$ и летние, без буквенного обозначенияч, высоковязкие и применяемые летом (SAE 20. 30, 40, 50, 60). Эксплуатируются и внесезонные классы масел, например, масло SAE 15W-40. Несмотря на то, что классификация SAE до сих пор жизнеспособна, по мере развития научно-технического прогресса возникла потребность в разработке более совершенных специализированных масел. Так, например, в 1947 г. на рынке появилась классификация американского Института нефти (API), которая усовершенствовала прежнюю классификацию SAE.

В наши дни для обозначения характеристик моторных масел и областей их практического использования принято использовать стандарты нескольких мировых классификаций, в том числе таких как [6]:

SAE - Сообщество автомобильных инженеров;

API - Американский институт нефти;

ACEA - Ассоциация европейских производителей автомобилей;

ILSAC - Международный комитет по стандартизации и одобрению смазочных материалов;

ГОСТ 17.479.1-85 - стандарт российских производителей.

Одна из последних модификаций классификации API под названием API Base Oil Classification, разделившая базовые масла на пять групп в зависимости от их происхождения и способа очистки (от Группы I до Группы V), была принята API в начале 1990-х годов (табл. 1) [7]. 
Классификация базовых масел согласно версии АРI [7]

\begin{tabular}{|c|c|c|c|c|c|}
\hline Группа & Характеристика & $\begin{array}{l}\text { Сера, } \\
\text { \% вес. }\end{array}$ & $\begin{array}{c}\text { Насыщенные } \\
\text { соединения }\end{array}$ & $\begin{array}{c}\text { Индекс } \\
\text { вязкости V.I. }\end{array}$ & Специфика \\
\hline I & $\begin{array}{l}\text { Депарафинизация и селек- } \\
\text { тивная очистка нефти. }\end{array}$ & $>0,03$ & $<90$ & $80-119$ & $\begin{array}{l}\text { Слишком большое } \\
\text { содержание серы. }\end{array}$ \\
\hline II & $\begin{array}{l}\text { Гидропереработка, меньше } \\
\text { парафинов и ароматики. }\end{array}$ & $\leq 0,03$ & $\geq 90$ & $80-119$ & \multirow{3}{*}{$\begin{array}{l}\text { Повышенный V.I. } \\
\text { Группа IV (традиционно } \\
\text { синтетическая), сейчас } \\
\text { включает в себя Группу III. }\end{array}$} \\
\hline III & $\begin{array}{l}\text { Каталитический крекинг, } \\
\text { уменьшенный V.I. }\end{array}$ & $\leq 0,03$ & $\geq 90$ & $\geq 120$ & \\
\hline IV & $\begin{array}{l}\text { Полиальфаолефины масла } \\
\text { с повышенной окислитель- } \\
\text { ной стабильностью и увели- } \\
\text { ченным V.I. }\end{array}$ & $<0,001$ & $>99,5$ & $>130$ & \\
\hline $\mathrm{V}$ & $\begin{array}{l}\text { Все масла, не включенные } \\
\text { в группы I-IV; } \\
\text { базовые синтетические и на- } \\
\text { туральные масла. }\end{array}$ & $\begin{array}{l}\text { Широкий } \\
\text { интервал }\end{array}$ & $\begin{array}{l}\text { Широкий } \\
\text { интервал }\end{array}$ & $\begin{array}{l}\text { Широкий } \\
\text { интервал }\end{array}$ & $\begin{array}{l}\text { Небольшие объемы произ- } \\
\text { водства (от очень высокого } \\
\text { до очень низкого качества). }\end{array}$ \\
\hline
\end{tabular}

Масла Группы I, относящиеся к чисто минеральным маслам, представляют собой смесь различных углеводородов, поэтому их свойства очень нестабильны (они сильно густеют при охлаждении и быстро окисляются при высоких температурах). Несмотря на то, что спрос на масла Группы I, главным преимуществом которых является их низкая цена, постепенно уменьшается (поскольку в их состав входит слишком много серы и ароматики), они все еще остаются самым крупным сегментом на мировом рынке моторных масел и доминируют на нем. Обычно масла Группы I производят из фракций сырой нефти по устаревшей технологии очистки, включающей экстракцию растворителями и депарафинизацию. Сейчас такая неэффективная технология обработки нефти, правда существенно модернизированная, применяется на небольших или морально устаревших заводах, которые в ближайшие 20 лет планируется закрыть. В основном масла Группы I используют в индустриальных смазках, смазочных материалах морских судов и моторных маслах в машинах старого поколения.

Масла Групп II и III имеют значительно более высокую степень очистки по сравнению с минеральными маслами. Их получают методами гидрообработки (hydroprocessing) нефти, в том числе методом гидроочистки и каталитического крекинга. Таким образом, такие масла являются гидрированными маслами с содержанием до 99 \% насыщенных соединений. Главное различие между Группами II и III состоит в том, что масла Группы III имеют индекс вязкости V.I. $\geq 120$. До сих пор более 90 \% всего объема смазочных материалов в мире изготовляется из масел Группы II, которые особо распространены на рынках Северной Америки, а интерес к маслам Группы III связан с их более высокой экономической эффективностью. Масла Группы III могут включать в себя и GTL-масла, получаемые не из нефти, а из природного газа по известной технологии GTL (gas-to-liquid). Например, масла GTL компании Shell имеют индекс вязкости 140, вязкость $4 \mathrm{Mм}^{2} / \mathrm{c}$ при $100{ }^{\circ} \mathrm{C}$, температуру застывания $-15{ }^{\circ} \mathrm{C}$ и испаряемость по Noak $<14$. Правда метод GTL в целом все еще остается очень сложным и дорогостоящим; он предназначен для реализации на очень крупных газовых месторождениях и для его коммерциализации требуются огромные инвестиции, в основном вызванные необходимостью использования громоздкого технологического оборудования, работающего при высоких давлениях.

Известно, что гидрокрекинг используют такие крупные мировые производители моторных масел, как компании Shell (кроме масла 0W-40) и ВР (кроме масла Visco 7000). Частично гидрокрекинг применяют компании Fuchs, Esso, Mobil, Chevron, Castrol, а южно-корейская фирма ZIC вообще производит все свои масла только с помощью гидрокрекинга.

Отмечается, что вплоть до 2003 г. производителям моторных масел удавалось использовать в качестве основных базовых масел гидрокрекинговые масла, поскольку получаемые на их основе смазочные материалы вполне соответствовали действующим тогда стандартам, применяемым к автомо- 
бильным маслам [8]. Однако, несмотря на постоянное совершенствование технологий производства моторных масел, появлялись и расширялись новые области их применения, где уровень отдельных характеристик гидрокрегинговых масел оказывался недостаточным. Это привело к необходимости разработки базовых моторных масел нового типа.

Такими базовыми маслами стали более совершенные синтетические базовые масла Группы IV, полностью однородные по химическому составу, что обеспечивало их высокую стабильность и долговечность. Синтетические базовые масла на основе полиальфаолефиновых масел (ПАО) производят из соответствующих мономеров (в основном - децена-1). Несмотря на явные конкурентные преимущества, мировые мощности по производству синтетических масел пока ограничены; они очень дорогостоящие и обычно применяются лишь в случаях, когда необходимы особые рабочие характеристики масел, например, стабильность работы при очень высоких или очень низких температурах. Используя смеси различных полиальфаолефинов, удается создавать масла с индексом вязкости V.I. на уровне 140. Применение ПАО пока ограничивается доступностью и высокой стоимостью сырья, поэтому они остро конкурируют с маслами других групп и занимают особую нишу на рынке смазочных материалов.

В масла Группы V входят другие компоненты, не вошедшие в четыре вышеперечисленные группы - нафтены, органические спирты, некоторые биоразлагаемые жидкости и полиалкиленгликоли, которые являются очень огнестойкими и могут ис- пользоваться в качестве высокотемпературных гидравлических топлив.

В наши дни мировые мощности по производству синтетических базовых масел исходя из входящих в их состав соединений располагаются следующим образом (масла, тыс. т/год): изопапарафиновые и GTL - 650; полиальфаолефиновые - 620; сложноэфирные - 220; полиалкиленгликолевые 80 ; олигоорганосилоксановые - 50; олигобутеновые - 30; прочие - 30; всего - 1740 [9].

Сравнение термоокислительной способности моторных масел в зависимости от типа исходного базового масла, на основе которого они получены, проиллюстрировано на рис. 1.

\section{2. Синтетические углеводородные масла}

Разработка синтетических базовых масел началась в конце XIX века, а с 1920 г. они уже выпускались в промышленных масштабах. Основным стимулом последующего развития мирового рынка синтетических масел стала острая необходимость использования в стремительно развивающейся авиационной промышленности таких смазочных материалов, которые бы обладали хорошей морозоустойчивостью и длительным сроком службы без потери основных рабочих характеристик.

\section{1. Соединения, используемье в качестве основ синтетических смазок}

В целом, к синтетическим углеводородным маслам относят следующие масла: полиальфао-

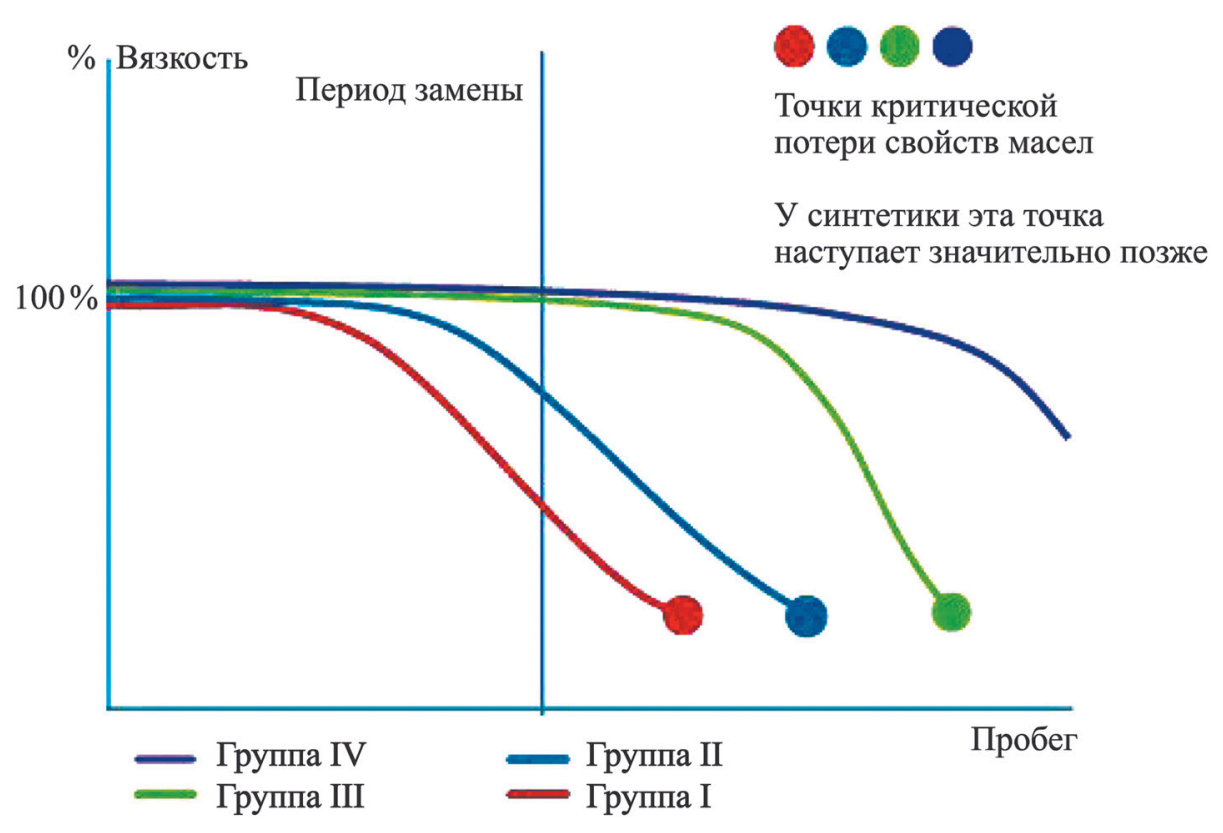

Рис. 1. Термоокислительная способность моторного масла в зависимости от типа базового масла [10] 
лефиновые, полиинтраолефиновые, олигобутеновые, алкилбензольные, алкилнафталиновые, масла по технологиям GTL, синтетические нафтены. Обычно синтетические масла представляют собой смеси химических соединений с одинаковой или сходной структурой. Была установлена взаимосвязь между химической структурой базового масла и его смазочными свойствами (температурой застывания, вязкостью и вязкостно-температурной характеристикой). Показано, что насыщенные алифатические углеводороды имеют невысокую вязкость, но удовлетворительные вязкостнотемпературные характеристики, причем вязкость увеличивается по мере увеличения длины цепи. Такая же зависимость обнаружена для температуры застывания и индекса вязкости, а также показано, что длина и положение боковых цепей в молекуле углеводорода влияют на все три важнейшие характеристики смазочных материалов. Более низкие температуры застывания имеют масла, имеющие разветвления в середине цепи, а длинные боковые цепи улучшают вязкостно-температурные характеристики.

Образование колец приводит к более сильному увеличению вязкости и снижению индекса вязкости при алкильном замещении. Парафиновые боковые цепи у нафтенового кольца оказывают противоположное влияние. Алкилированные ароматические углеводороды имеют более низкую вязкость и менее благоприятные вязкостно-температурные характеристики.

Основные типы структур углеводородов, входящих в состав масел, согласно [11], представлены на рис. 2.

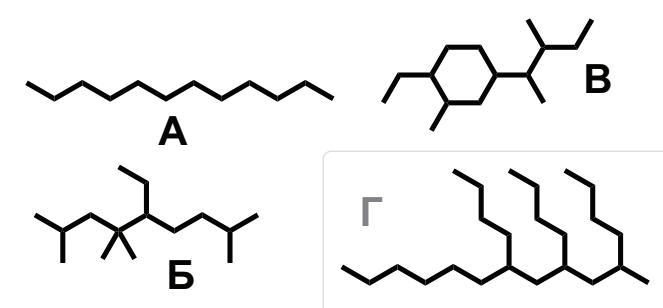

Рис. 2. Основные структурные типы углеводородов, входящих в состав моторных масел:

zpynna I: A, Б; zpynna II: A, Б; гpynna III: $\mathbf{~}, \mathbf{B}$; zpynna IV: $\mathbf{6}, \mathbf{B}, \mathbf{\Gamma}[11]$

Длинные линейные углеводороды (нефтяные парафины) (Рисунок 2А), составляющие наибольшую часть масел Групп I и II, имеют высокие температуры застывания, поэтому их нельзя использовать при низких температурах. Масла Группы III, содержащие соединения с короткими от- ветвлениями (Рисунок 2Б) и циклоалканы (Рисунок 2B), также имеют относительно высокие значения РР и кинематической вязкости $\mathrm{KV}^{-40}$. Разветвленные углеводороды с длинными цепями (Рисунок 1 ) характеризуются низкими РР и высокими VI. Единственной возможностью получить углеводороды со структурой Г является олигомеризация альфаолефинов и последующее гидрирование образующихся при этом продуктов [12].

Олигомеризация альфаолефинов дает возможность получать полиальфаолефиновые масла с хорошими вязкостно-температурными характеристиками. Например, отличным сырьем для получения ПАО служит децен. Комбинацией молекул децена образуется ряд олигомеров, из которых затем путем дистилляции получают базовые масла различных классов вязкости, не содержащие примесей. Отсутствие линейных парафинов снижает естественную температуру застывания до очень низких значений (как правило, она ниже $\left.-50{ }^{\circ} \mathrm{C}\right)$. Отсутствие в таких маслах примесей, которые всегда служат катализаторами старения масел, делает синтетическое базовое масло весьма устойчивым к воздействию высоких температур (они выдерживают температуры до $150{ }^{\circ} \mathrm{C}$ без потери рабочих свойств). Отсутствие случайных молекул малого размера обеспечивает низкую летучесть синтетических масел на основе ПАО по сравнению с минеральными маслами.

Другими представителями синтетических базовых масел являются диэфирные масла, получаемые при взаимодействии двухосновных кислот с одноатомными спиртами или одноосновных кислот с многоатомными спиртами. Диэфиры имеют более разнообразную структуру, чем ПАО, и характеризуются целым рядом преимуществ. Они обладают хорошей смешиваемостью с минеральными маслами. По сравнению с минеральными, масла на базе диэфиров обладают более высокими индексами вязкости и термостабильностью, более низкими температурами застывания, меньшей летучестью и огнеопасностью. Высокая растворяющая способность позволяет им растворять лаки и шламы, тем самым поддерживая чистоту деталей двигателя. Кроме того, практика показала, что диэфирные масла способны удалять в двигателе отложения, образованные в результате применения других смазочных материалов.

К недостаткам диэфирных синтетических масел относят их повышенную агрессивность по отношению к натуральным и синтетическим резинотехническим изделиям, что приводит к их набуханию и размягчению. Поэтому диэфирные масла советуют использовать с химически инертными уплотнительными материалами. 
Характеристики углеводородных масел на основе полиальфаолефинов и диэфиров [8]

\begin{tabular}{ccccccc}
\hline Тип масла & $\begin{array}{c}\text { Динамич. } \\
\text { вязкость } \\
\text { при } \mathbf{- 4 0}{ }^{\circ} \mathbf{C}, \mathbf{c P}\end{array}$ & $\begin{array}{c}\text { Кинемат. } \\
\text { вязкость } \\
\text { при } \mathbf{4 0}{ }^{\circ} \mathbf{C}, \mathbf{c S t}\end{array}$ & $\begin{array}{c}\text { Кинемат. } \\
\text { вязкость } \\
\text { при 100 }{ }^{\circ} \mathbf{C}, \mathbf{c S t}\end{array}$ & $\begin{array}{c}\text { Индекс } \\
\text { вязкости }\end{array}$ & $\begin{array}{c}\text { Темпер. } \\
\text { застывания, } \\
{ }^{\circ} \mathbf{C}\end{array}$ & $\begin{array}{c}\text { Темпер. } \\
\text { вспышки, } \\
{ }^{\circ} \mathbf{C}\end{array}$ \\
\hline РАО 4 & 2371 & 18,12 & 3,96 & 126 & -79 & 221 \\
РАО 6 & 8176 & 34,07 & 6,00 & 134 & -68 & 243 \\
Диэфиры & - & 95,00 & 13,40 & 142 & -42 & 300 \\
\hline
\end{tabular}

В табл. 2 приводятся характеристики наиболее распространенных на рынке базовых масел на основе полиальфаолефинов и диэфиров.

\section{2. Преимущуества и недостатки синтетических моторных масел по сравнению с традиционными минеральными маслами}

Преимущества: улучшенная энергетическая эффективность; широкий ряд рабочих температур; отсутствие азота, серы или других элементов, которые ведут к образованию шламов и таким образом к порче двигателей; улучшенная огнестойкость, термическая стабильность, стойкость к окислению, радиации и др.; облегченное техническое обслуживание и безопасность работы.

Однако, несмотря на явные преимущества, синтетические основы моторных масел остаются пока весьма дорогостоящими и в настоящее время испытывают явную конкуренцию с приобретающими все большую популярность на рынке экологичными смазками и би-омаслами [13].

Недостатки: полиэфирные масла на основе эфиров фосфорной кислоты обладают недостаточными индексами вязкости (в пределах от 0 до -30); фторуглеводородные масла имеют низкую температуру кипения и плохие вязкостно-температурные характеристики; силиконовые масла не смешиваются с минеральными и обладают недостаточными смазывающими и противоизносными свойствами; стоимость эфиров пока слишком велика (они в 5-10 раз дороже минеральных базовых масел), поэтому их добавляют в масла в количестве всего 3-5 $\%$, и то, как правило, в самые качественные и, соответственно, самые дорогие сорта моторных масел.

Из известных синтетических углеводородных масел более подробно остановимся на рассмотрении полиальфаолефиновых масел.

\section{3. Полиальфаолефиновые основы синтетических моторных масел}

Первое в мире массовое производство синтетическое моторное масло на основе полиальфао- лефинов осуществила компания Mobil Oil в 1974 г. по своей собственной разработке, когда возникла острая необходимость обеспечения работы авиационных двигателей в экстремально холодных условиях. Выпуск этого масла оказался настоящим революционным прорывом и только после этого ПАО стали производиться в массовых количествах не только для нужд авиации, но также и в автомобилестроении.

\section{1. Разновидности полиальфаолефиновых масел}

Олигомеризация пропилена позволяет получать масла с умеренным индексом вязкости и низкой термической стабильностью. При управлении реакцией полимеризации за счет регулирования скоростей роста или обрыва цепи можно получать продукты с различными вязкостными и вязкостно-температурными характеристиками. В качестве катализаторов могут использоваться $\mathrm{AlBr}_{3}$ c $\mathrm{HBr}$ или $\mathrm{BF}_{3}$ в хлорированных углеводородах. Практика показала, что свойства масел, полученных при олигомеризации пропилена, оказываются недостаточно хорошими из-за высокой степени разветвленности цепи и содержания третичных атомов водорода.

Особое внимание в последнее время уделяется сополимерам, синтезированным из эквимолярных смесей этилена и пропилена. Их получают полимеризацией с использованием катализаторов, препятствующих изомеризации цепи, в присутствии водорода с последующим частичным расщеплением в процессе термического крекинга, после чего получаемые продукты подвергают гидрогенизации и фракционированию. Фракции таких масел обладают различной вязкостью (индекс вязкости может доходить до 140) и низкие температуры застывания (вплоть до $\left.-54{ }^{\circ} \mathrm{C}\right)$. Они также характеризуются высокой стойкостью к окислению до 200 ${ }^{\circ} \mathrm{C}$ и термической стабильностью до $315{ }^{\circ} \mathrm{C}$, однако низкотемпературные характеристики этих масел неудовлетворительны. Такие ПАО можно также получать сополимеризацией при высоком давлении водорода без термического крекинга. 
Полиизобутены с молекулярными массами в пределах 300-1500 используют в качестве присадок, улучшающих индекс вязкости (полимеризация с $\mathrm{BF}_{3}$ в метаноле). Несмотря на низкие температуры застывания и коксуемость, их применение ограничено из-за невысокой стойкости к окислению, что приводит к увеличению вязкости масла. При температурах выше $200{ }^{\circ} \mathrm{C}$ они деполимеризуются с образованием газообразных продуктов. Главным образом полиизобутены используют для смазывания движущихся деталей устройств в обжиговых печах или в печах прокаливания, а также в качестве базового компонента специальных пластичных смазок. Наряду с другими полиолефинами, они рекомендованы к применению в электрических изоляционных устройствах, в качестве масел для двухтактных двигателей и двигателей Ванкеля, гидравлических и смазочно-охлаждающих жидкостей.

Наибольший интерес представляют полимеры высших олефинов. Вязкостно-температурные характеристики масел, получаемых на их основе, сильно зависят от исходно используемого олефина: разветвленные $\alpha$-олефины дают более низкие значения индекса вязкости, чем олефины с прямой цепью, а с качеством масел, полученных с использованием $\beta$-олефинов, дела с индексами вязкости обстоят еще хуже. Правда индекс вязкости по мере увеличения молекулярной массы исходного олефина повышается. Пентен-1 и изопентен позволяют получать масла вязкостью $21-30 \mathrm{~mm}^{2} / \mathrm{c}$ при $100{ }^{\circ} \mathrm{C}$ и индексом вязкости до 100. Современные олефиновые полимерные масла обычно подвергают гидроочистке.

В связи с большим спросом на высокоиндексные масла в последние годы широко применяют экономичный способ термической полимеризации олефинов. На базе нормальных альфаолефинов получают масла с индексом вязкости до 150 , низкой испаряемостью и повышенной окислительной и термической стабильностью. Олефины с 6-12 атомами углерода превращаются в масла при температурах до $500{ }^{\circ} \mathrm{C}$ в присутствии газов (например, $\mathrm{CO}$ и $\mathrm{H}_{2}$ ) или циклических углеводородов (алкилциклогексанов, алкилбензолов и т. п.) при очень коротком времени пребывания в реактоpe. Введение небольших количеств парафинов оказывает положительное влияние на вязкостно-температурные характеристики масла.

В процессе двухступенчатой термической полимеризации можно также получить продукты с особенно высоким индексом вязкости. Исходное сырье (линейные альфаолефины) получают в процессе парофазного крекинга парафинов, газойля или нефтяных дистиллятов селективной очист- ки. В результате полимеризации фракции $\mathrm{C}_{5}-\mathrm{C}_{20}$ олефинов в течение 2 ч при $315{ }^{\circ} \mathrm{C}$ и давлении 1,3-2,7 МПа образуются масла, которые после удаления непрореагировавших олефинов перегонкой приобретают индекс вязкости 56. На второй ступени термической полимеризации из отработанных олефинов после гидроочистки и депарафинизации получают масла с индексом вязкости выше 100 .

Особое значение имеет полимеризация альфа-олефинов $\mathrm{C}_{8}-\mathrm{C}_{12}$ в присутствии катализаторов Циглера или катализаторов на основе галогенидов алюминия [14]. Высокая концентрация олефинов с нечетным числом атомов углерода в сырье может привести к нежелательным результатам. Индексы вязкости этих продуктов превышают 130, температуры вспышки около $225^{\circ} \mathrm{C}$, а температуры застывания находятся на уровне $-60^{\circ} \mathrm{C}$. Аналогичным способом для получения смазочных масел можно проводить сополимеризацию альфа-олефинов с ненасыщенными галогенсодержащими соединениями или сложными эфирами карбоновых кислот.

Таким образом, полиальфаолефиновые масла можно получать из этилена в три стадии при определенных условиях (давление, температура, кратность и время циркуляции) в специальных реакторах с использованием катализатора. На первой стадии процесса (получение альфаолефинов) давление в реакторе достигает 200 атм, а температура до $200^{\circ} \mathrm{C}$, а на второй стадии (олигомеризация альфаолефинов) уже создается вакуум $\sim 50$ мм.рт.ст. Третья стадия представляет собой гидрирование полученных продуктов на стандартных катализаторах. Сложность технологии производства полиальфаолефиновых масел обуславливает их более высокую стоимость по сравнению с маслами, полученными из нефти по традиционной технологии.

\section{2. Преимущества и недостатки ПАО}

Преимущества. Высокие индексы вязкости позволяют использовать полиальфаолефиновые масла в широком диапазоне температур; отсутствие примесей соединений серы и металлов обеспечивает высокие антикоррозионные свойства; хорошая смешиваемость с минеральными маслами дает возможность использовать полиальфаолефины в качестве синтетических компонентов и при производстве полусинтетических масел; благодаря невысокой стоимости по сравнению с другими синтетическими маслами, ПАО используются наиболее широко и успешно.

К преимуществам также относятся очень низкие температуры застывания из-за отсутствия линейных парафинов, высокая термостабильность 
и стойкость к окислению ввиду отсутствия ненасыщенных углеводородов, а также малые летучесть и коксуемость, обеспечиваемые однородностью состава.

Эти качества стали особенно важны в последние годы в связи с увеличивающимся потреблением маловязких моторных масел в зарубежных автомобилях, рассчитанных на расширенные интервалы обслуживания по замене смазочных материалов. В связи с этим наблюдается заметное увеличение объемов продаж полиальфаолефиновых моторных масел для первичной заливки в двигатели непосредственно на автомобилестроительных заводах и при сервисном обслуживании моделей автомобилей нового выпуска.

Важной характеристикой ПАО является их биоразлагаемость, которая также зависит от молекулярной структуры углеводорода. Показано, что присутствие четвертичных атомов углерода блокирует окислительный распад углеводородов в окружающей среде [15] и установлено [16], что ПАО на основе децена-1 имеют удовлетворительную биоразлагаемость, превышающую этот показатель для масел Группы III.

Известно, что помимо моторных, на основе синтетических базовых масел ПАО успешно выпускают гидравлические, авиационные и компрессорные масла с высокими рабочими характеристиками.

Недостатки. Худшая по сравнению с минеральными маслами растворяющая способность по отношению к некоторым типам присадок и худшая совместимость с эластомерами (вызывают усадку резиновых уплотнений с потерей их эластичности). Эти недостатки можно устранить добавками небольших количеств сложных эфиров.

\section{4. Тенденции развития технологий получения базовых моторных масел}

Первые считающиеся классическими технологии получения базовых масел связаны с обработкой сырой нефти, содержащей минеральные компоненты, по классической схеме: селективная очистка растворителями (экстракция) $\rightarrow$ депарафинизация растворителями $\rightarrow$ очистка адсорбентами. При этом в зависимости от химического состава нефти образуются два типа масел - парафиновые и нафтеновые масла (так называемого начального и вполне достаточного уровня качества).

Естественно, что технологии получения масел на основе нефтяного сырья совершенствовались во времени. Появились процессы гидрообработки, которые смогли частично или полностью заменить классические методы очистки нефти с получени- ем гидроочищенных и гидрокрекинговых базовых масел. Так, легкая гидроочистка без применения высоких давлений и температур позволяет дополнительно улучшать качество масел (цвета, запах), а также удалять остатки нежелательных серы, азота и олефинов.

Более совершенная глубокая гидроочистка протекает с использованием высоких давлений и температур, а также специальных катализаторов. Сюда относятся каталитический крекинг и последующая гидроизомеризация, а получаемые при этом гидрокрекинговые базовые масла обладают высоким качеством, приближающим их к показателям синтетических масел.

Обычно синтетические смазочные материалы на основе олефинов $\mathrm{C}_{3}-\mathrm{C}_{14}$ получают путем их олигомеризации с применением катионных катализаторов, преимущественно на основе треххлористого алюминия. Известные катализаторы таких процессов характеризуются низкой активностью и функционируют в области технически неблагоприятных температур (ниже $+30^{\circ} \mathrm{C}$ ), что требует больших энергетических затрат для обеспечения съема тепла олигомеризации. Процесс проводят в громоздких, металлоемких низкопроизводительных (до одной тонны олигомеров с кубического метра реакционного объема в час) реакторах смешения емкостного типа в изотермических условиях. В качестве растворителя используют углеводороды или хлорбензол. Отработанный катализатор из олигомеризата выделяют путем отмывки водно-щелочными растворами, что приводит к образованию большого количества трудно утилизируемых стоков и увлажнению олигомеров. С целью повышения термоокислительной стабильности олигоолефинов их гидрируют на малоактивных никельсодержащих катализаторах в весьма жестких условиях $\left(\mathrm{T}=300{ }^{\circ} \mathrm{C}, \mathrm{P}=200\right.$ ат). Все это в совокупности обуславливает сложное технологическое оформление и относительно низкие технико-экономические показатели таких процессов.

Таких недостатков лишена технология получения ненасыщенных, гидрированных и ароматизированных олигоолефиновых основ синтетических смазочных материалов, представленная в [17]. Авторами разработаны оригинальные высокоактивные растворимые алюминийорганические катионные катализаторы, функционирующие при температурах от 0 до $+150{ }^{\circ} \mathrm{C}[18]$. Под действием этих катализаторов в оптимальных условиях при температурах $120-150{ }^{\circ} \mathrm{C}$ достигается 90-95\% конверсия олефинов в течение 30-180 сек. В результате олигомеризации пропилена, бутенов и высших олефинов (в частности, децена-1) образуются совершенно бесцветные олигомеры, представ- 
ляющие собой высокоразветвленные углеводороды с небольшой молекулярной массой (250-2000) и узким молекулярно-массовым распределением $\left(\mathrm{M}_{\mathrm{w}} / \mathrm{M}_{\mathrm{n}}=1,10-1,40\right)$.

Традиционно, основы масел Группы IV получают путем олигомеризации альфаолефинов, а при крупномасштабном производстве ПАО с низкой вязкостью применяют электрофильный катализ со скелетной изомеризацией. В частности, вдоль углеродной цепи генерируется много метильных групп в произвольном положении [19], а некоторых случаях образуются и алициклические продукты [20-22]. Такие скелетные изомеризации приводят к получению сложных углеводородных смесей, содержащих побочные компоненты с более низкими индексами вязкости, чем должны присутствовать в высокоразветвленных углеводородах. Альтернативный этому процесс - координационная полимеризация, которая исследована в присутствии различных каталитических систем. Выяснилось, что координационная олигомеризация в присутствии гетерогенных титан-алюминиевых и хромовых катализаторов Циглера-Натта также сопровождается скелетными перегруппировками. Изомеризация скелетона наблюдалась даже в случае олигомеризации, катализируемой диметилцирконоценами, активированными перфторборатами и постметаллоценовыми катализаторами $[23,24]$.

Нежелательные побочные реакции наблюдаются в минимальных количествах при олигомеризации альфаолефинов, которая катализируется цирконоцен дихлоридами $\left(\mathrm{LZrCl}_{2}\right)$, активированными метилалюмоксаном (МАO) [25]. В этом случае рост цепи происходит только в положениях 1,2 и лимитируется выделением или $\beta$-гидридным переносом. В результате продукты этого процесса представляют собой альфаолигомеры винилиденового типа с одинаковой молекулярной структурой, которые непригодны для использования в качестве базовых ингредиентов масел из-за низкого индекса вязкости и высокой температуры застывания.

В частности, группой российских ученых из Института нефтехимического синтеза им. Топчиева РАН, Московского государственного университета им. М.В. Ломоносова и Института проблем химической физики РАН был предложен оригинальный подход к решению проблемы олигомеризации альфаолефинов и разработаны новые стабильные цирконоценовые катализаторы для осуществления этих процессов [26]. Этот метод позволяет достичь $90 \%$ выхода фракций альфаолефиновых олигомеров без значительного образования побочных продуктов (алкенов, алканов, высших олигомеров). Показано, что выделенные заме- щенные олигомеры 1-октена и 1-децена превосходят продукты традиционной электрофильной олигомеризации по таким показателям, как индексы вязкости, температуры застывания и вязкости при низких температурах.

Научные исследования по созданию новых эффективных промышленных технологий получения базовых моторных масел, соответствующих потребностям современного рынка, с тем или иным успехом активно продолжаются и в наши дни.

\section{5. На мировом рынке синтетических моторных масел}

\section{1. Краткая история возникновения рынка}

Несмотря на постоянное совершенствование технологий получения высококачественных гидрокрекинговых масел, области их применения в последнее время настолько расширились, что принятого уровня их качества стало недоставать. Так, например, традиционные гидрокрекинговые масла проявляют недостаточную стойкость к окислению и обладают относительно высокой летучестью.

Первыми синтетическими моторными маслами, которые применили на практике в авиации и военной технике, были масла на основе высокомолекулярных углеводородов, представляющих собой полиалкиленгликоли (ПАГ), полученные в процессе Фишера-Тропша в Германии во времена Второй Мировой Войны. Параллельно с разработкой полиалкиленгликолевых масел для реактивных авиационных двигателей разрабатывались и синтетические масла на основе сложных эфиров. Считается, что первые коммерческие синтетические моторные масла на основе ПАГ выпустила в 1946 г. компания National Carbide Company. В 1966 г. французская фирма Motul сначала представила моторное масло Century 2100, содержащее синтетическое компоненты («полусинтетическое»), а в 1971 г. - полностью синтетическое моторное масло Century 300V. В 1972 г. Американский институт нефти API впервые официально одобрил синтетическое масло марки Amsoil, созданное на основе сложных эфиров, однако масштабы его выпуска оказались весьма скромными.

Случившийся в начале 1970-х годов мировой нефтяной кризис резко повысил интерес к синтетическим смазочным материалом. Так, в 1974 г. на рынке появилось синтетическое масло стандарта SAE 5W-20 на базе полиальфаолефинов под названием Mobil 1, созданное компанией Mobil. Позже для улучшения качества и рабочих характеристик в моторные масла на основе ПАО стали 
добавлять присадки. Параллельно улучшались и технологии подготовки традиционных минеральных моторных масел: так появился процесс гидроочистки базовых масел, позволивший значительно снизить в них содержание сернистых соединений и иных посторонних примесей, за счёт чего повысилась химическая стойкость этих масел и снизилась их коррозионная активность.

В 1980 году Mobil представила синтетические масла Mobil 1 нового поколения (стандарты SAE 5W-30 и 15W-50), а в начале 1990-х годов синтетические моторные масла начинают появляться в линейках продукции компаний Chevron, Valvoline, Castrol, Texaco, Pennzoil и ряда других. Одновременно с этим при производстве традиционных минеральных базовых масел массовое распространение получил двухступенчатый процесс гидрокрекинга. При этом уже к середине 1990-х годов практически все ведущие компании-производители смазочных материалов помимо гидрированных минеральных масел стали выпускать и полностью синтетические моторные масла, сегмент которых на рынке стал возрастать. В 2017 г. мировые производственные мощности по полиальфаолефиновым маслам составили 620 тыс. тонн в год и, согласно прогнозам, к 2025 г. должны достичь 815 тыс. тонн в год [9].

\section{2. Общее положение на современном рынке синтетических моторных масел}

В наши дни главной движущей силой развития мирового рынка синтетических смазочных материалов является растущий спрос на автомобили со стороны развивающихся экономик Китая, Индии и Индонезии. К другим важным факторам, влияющим на становление рынка, относят рост информированности покупателей относительно преимуществ тех или иных масел, а также ужесточающиеся нормы регулирования качественных характеристик смазочных материалов правительствами многих стран на уровне мировых стандартов.

Сейчас самая большая доля на мировом рынке смазочных материалов по-прежнему принадлежит минеральным маслам (включая так называемые гидрообработанные и гидрокрекинговые масла высокой степени очистки). Благодаря низкой стоимости и легкой доступности их применение растет практически во всех секторах рынка. Лидирующей областью применения является транспорт, особенно в связи с быстрым развитием автомобилестроения, авиации и морских судов в странах АзиатскоТихоокеанского Региона (АТР).

Еще совсем недавно крупнейшим региональным рынком синтетических смазочных матери- алов была Европа, а следом за ней следовала Северная Америка. В настоящее время рынок стран АТР явно опережает европейский рынок, при этом ожидается, что в ближайшем будущем самыми быстрорастущими региональными рынками станут Ближний Восток и Африка.

Основная доля на мировом рынке синтетических смазок принадлежит полиолефиновым моторным маслам, что, как мы отмечали выше, связано с их отличными эксплуатационными характеристиками (низкая летучесть, высокий индекс вязкости, низкая температура застывания, улучшенная окислительная и термическая стабильность). Ассортимент полиальфаолефиновых масел на мировом рынке представлен маслами: РАО-2 PAO-10; PAO-40 - PAO-100; PAO-300 - PAO-2000; Lucants HC-40 - HC-2000.

Сырьем для синтеза полиальфаолефиновых масел являются альфаолефины, мировые мощности по производству которых, согласно информации, почерпнутой из данных [9], представлены в табл. 3.

Из данных Таблицы 3 следует, что самые большие производственные мощности по производству альфаолефинов сосредоточены в США, а единственное отечественное производство находится в ведении ОАО «Нижнекамскнефтехим» (лицензия "SABIC-Linde").

Моторные масла являются ведущим сегментом рынка по использованию синтетических смазочных материалов, чему, как мы отмечали выше, способствует быстрое развитие автомобильной промышленности в странах АТР, наблюдаемое в последнее время. Особо заметна на рынке роль водорастворимых масел на основе полиалкиленгликоля (ПАГ), которые широко используются в качестве смазок для металлических поверхностей, соприкасающихся при работе с жидкостями, обладают деформационной стабильностью и высокими индексами вязкости, являясь при этом хорошими теплоносителями.

\section{3. Ведущие компании-производители на рынке моторных масел}

В настоящее время на мировом рынке синтетических моторных масел действует ряд ключевых игроков, которые представлены следующими компаниями: ExxonMobil Corporation (США); Royal Dutch Shell Plc. (Нидерланды); Fuchs Petrolub SE (Германия); Total S.A. (Франция); Chevron Corporation (СШA); Lubrizol Corporation (СШA); Idemitsu Kosan Co. Ltd (Япония); Pennsoil (США); The Dow Chemical Company (СШA); Petroliam Nasional Berhad (Малайзия). 
Таблииа 3

Мировые мощности альфаолефинов как основного сырья для производства полиальфаолефиновых масел

\begin{tabular}{|c|c|c|c|}
\hline Страна & Компания & $\begin{array}{l}\text { Мощности } \\
\text { (тыс. т/год) }\end{array}$ & $\begin{array}{c}\text { Месторасположение } \\
\text { производства }\end{array}$ \\
\hline & "ChevronPhillips Chemical Co." & & Cedar Bayou (Texac) \\
\hline \multirow[t]{2}{*}{ США } & "BP Amoco" & 1450 & Pasadena (Texac) \\
\hline & "Shell" & & Geismar (Луизиана) \\
\hline Бельгия & “Ineos” (США) & 300 & Feluy \\
\hline Великобритания & "Shell" & 270 & Stanlow/Carrington \\
\hline Канада & “Ineos” (США) & 250 & Joffre (Альберта) \\
\hline ЮАР & "Sasol Olefins \& Surfactants" & 177 & Secunda \\
\hline Саудовская Аравия & CП "SABIC-Linde" & 150 & Jubail \\
\hline \multirow[b]{2}{*}{ Япония } & "Mitsubishi" (по лицензии Shell) & & Ichihara \\
\hline & $\begin{array}{l}\text { "Idemitsu Kosan Co. Ltd.” } \\
\text { (по лицензии Shell) }\end{array}$ & 105 & Kurashiki \\
\hline Россия & $\begin{array}{l}\text { ОАО «Нижнекамскнефтехим» } \\
\text { (по лицензии “SABIC-Linde”) }\end{array}$ & 38 & Нижнекамск \\
\hline
\end{tabular}

Известны также синтетические моторные масла таких компаний, как Castrol, British Petroleum, Kao Corporation, Petro Canada, Petro China, Gulf Oil Middle-East, Lukoil, NOF Corporation, Valvoline, Sinopec, Petronas и др.

Синтетические полиолефиновые моторные масла в 2017 г. производили следующие ведущие мировые компании: Ineos Oligomers (202 тыс. т/г), Exxon Mobil Chemical (199,5 тыс. т/г), Chevron Phillips Chemical (108 тыс. т/г), Chemtura (31,8 тыс. т/г); Mitsu Petrochemical Industri (10 тыс. т/г), ООО «Татнефть-НКНХ-Ойл» (10 тыс. т/г).

Что касается мирового рынка присадок к моторным маслам, то в настоящее время он практически полностью поделен между крупными транснациональными корпорациями. Так, около 40 \% моторных масел в мире готовится на основе пакетов присадок, предоставляемых компанией Lubrizol, ещё приблизительно столько же - компанией Infineum, а менее 20 \% рынка приходится на остальных игроков (компании Chevron Oronite, TCM Afton Chemical, British Petroleum, ВНИИ НП, НПП «Квалитет» и др.). Отметим при этом, что обычно используемые пакеты присадок весьма схожи по составу или даже полностью идентичны и только ограниченное число компаний-производителей по всему миру предлагает действительно уникальные и инновационные пакеты присадок к моторным маслам.

\section{4. Мировой спрос на моторные масла}

В последние 20 лет мировой спрос на моторные масла находился в сильной зависимости от состояния мировой экономики и роста валового внутреннего продукта. Так, поскольку, начиная с 2011 г. мировой валовой продукт стал уменьшаться, то к 2015 г. спрос на моторные масла также уменьшился (на 600 тыс. тонн), а в 2016 г. падение производства составило 500 тыс. тонн. Многие эксперты рынка делали предположения, что в 2015 и 2016 гг. спрос на масла будет плавно снижаться, в 2017 г. спад приостановится, а затем будет слабо расти по мере того, как мировая экономика станет восстанавливаться [27].

Не все регионы демонстрируют одинаковые скорости роста или падения спроса на моторные масла (в частности, в странах Европы и Северной Америки спрос снижался от 1,0 до 1,5 \% в год). В самое ближайшее время сильный рост спроса ожидается в развивающихся экономиках стран Азии, Ближнего Востока и Африки, а Южная Америка будет отставать от этих регионов из-за слабых экономик таких стран, как Бразилия, Венесуэла и Аргентина. К 2020 г. почти половина мирового спроса на моторные масла будет исходить от стран АТР. При этом потребность в них в Европе, включая Россию, будет составлять лишь около одной шестой части от общего мирового производства.

\section{5. Предложение моторных масел на рынке}

В связи с состоянием дел в мировой экономике в последние три года закрылось около 2,6 млн тонн мощностей по выпуску моторных масел, а большое количество заявленных на эти годы проектов были отложены на период после 2020 г., если вообще бу- 
дут реализованы. За период 2015-2016 гг. были отклонены свыше 4 млн тонн в год предварительно проанонсированных дополнительных мощностей по производству моторных масел.

Сложившаяся конъюнктура рынка показывает, что низкие цены на сырую нефть существенно сократили затраты на капитальные вложения среди интегрированных нефтяных компаний. Фактически это привело к большому переизбытку базовых моторных масел, а также к снижению доступа к высокостоимостной парафинистой сырой нефти, которую, например, компания HollyFrontier запланировала для производства базовых масел группы Group+. Другим фактором послужили санкции против России, что сократило доступ к капиталам и технологиям таких наших крупных нефтегазовых компаний, как ГазпромНефть и Зарубежнефть.

Несмотря на то, что в результате отсрочек и даже полных отказов количество дополнительных мощностей по производству моторных масел, запланированных на 2014-2015 гг., значительно снизилось, тем не менее, согласно прогнозам, к 2020 г. все-таки в строй должны будут введены около 17 из запланированных мощностей. Из них пять мощностей были запущены в 2015 г. (от 1,1 до 1,2 млн т/г), пять - в течение 2016 г. (2,2 млн т/г). Еще четыре дополнительных мощностей будут введены в строй в течение 2018 г. и 2019 г. (суммарно 800 тыс. т/г), а три - к концу 2020 г. (2,5 млн т/г). Ввод этих дополнительных мощностей, включающих полиальфаолефиновые и нафтеновые мас- ла, должен привести к постепенному увеличению мировых производственных мощностей [27].

Сейчас некоторые заводы по выпуску масел группы Group I работают в непрерывном режиме при очень низких нагрузках. Постепенный отказ от масел Group I продолжается, а масла группы Group II быстро занимают освобождающуюся нишу благодаря хорошим эксплуатационным показателям. Ожидается, что из региональных рынков в 2020 г. крупнейшим производителем моторных масел станет Азия, масла группы Group II будут сильнее доминировать в Северной Америке и странах Азии, тогда как Южная Америка продолжит ограничиваться маслами группы Group I (рис. 4).

Во всех регионах будет наблюдаться снижение поставок масел группы Group I (сильнее всего в Европе), при этом в Европе и на Ближнем Востоке появятся первые крупные мощности по выпуску масел группы Group II. Отклонение или даже ликвидация многих проектов продолжит наблюдаться в Южной Америке (здесь возрастет импорт масел группы Group II), а Северная Америка и Азия по-прежнему останутся главным источником поставок масел группы Group II на другие региональные рынки. Увеличение мощностей по производству масел группы Group III к 2020 г. будет незначительным. Главными импортерами масел группы Group III, которые в основном будут поставляться из стран Азии и Ближнего Востока, останутся Северная и Южная Америка.

Предложение базовых масел по регионам, 2020

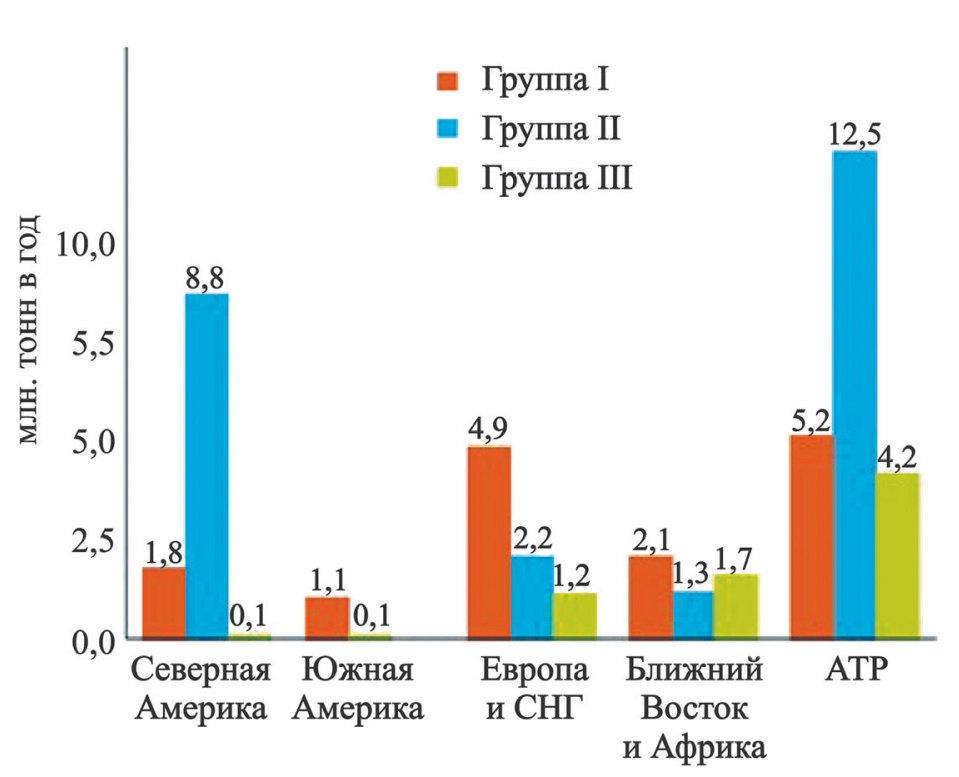

Рис. 4. Региональное предложение базовых масел в 2020 г. (прогноз) [27] 


\section{6. Прогноз развития мирового рынка смазок}

Мировой рынок смазочных материалов в целом, включая минеральные, синтетические, биомасла и густые смазки (greases), в 2015 г. оценивался в 144,45 млрд. долларов. Согласно прогнозам аналитической компании MarketsandMarkets, в период 2016 - 2021 рынок будет расти со скоростью $2,4 \%$ в год и к 2021 г. достигнет значения в 166,59 млрд долларов, а самым быстро развивающимся рынком моторных масел всех видов будет АТР [2].

Что касается мирового рынка непосредственно синтетических смазочных материалов, включая ПАО, сложные эфиры, масла ІІІ группы и полиалкиленгликоли, то в 2014 г. он оценивался в 31,0 млрд долларов и, согласно прогнозам MarketsandMarkets, к 2020 г. должен достичь 36,0 млрд долларов при среднегодовом росте в $2,5 \%$ в период между 2015 и 2020 гг. [28, 29]. Рынок синтетических моторных масел в США, согласно прогнозам компании Freedonia Group, в 2018 г. должен увеличиться до 27,5 млрд долларов [30]. Хотя рост американского рынка в период 2018-2023 гг. ожидается весьма умеренным, все-таки это будет прогрессом по сравнению с полным упадком рынка в 20082013 гг. В качестве синтетических моторных масел здесь обычно используют сложные эфиры дикарбоновой, фосфорной и кремниевой кислот и их смеси, а также полигликоли, силоксаны, политетрафторэтилен.

\section{6. Рынок моторных масел в России}

Российский рынок смазочных материалов, охватывающих смазочные масла (самый большой процент от общего объема), пластичные смазки и суспензии для нанесения твердых смазочных покрытий, является крупнейшим в Европе (20 \% от европейского спроса) и пятым по величине в мире. В настоящее время на российском рынке наблюдаются серьезные структурные изменения технического характера, а также активно развивается тенденция к импортозамещению.

Рынок моторных масел в России можно условно разделить на два сегмента. Первый представлен внутренним производством, куда входят крупные отечественные нефтедобывающие и нефтеперерабатывающие компании, которые располагают возможностями для производства не только автомобильных масел, но и присадок к ним, а также иных смазочных материалов широкого профиля использования. Во второй сегмент входят иностранные производители смазочных масел известных мировых брендов [31]. Отечественный рынок характеризуется высокой конкуренцией: в борьбе за рос- сийского потребителя принимают участие как отечественные, так и зарубежные компании с мировыми именами, в результате чего автовладельцам предоставляются широкие возможности выбора как по ценовым категориям, так и по видам масел и их эксплуатационным характеристикам.

\section{1. Российские компании по производству моторных масел}

Основные производители моторных масел на отечественном рынке представлены крупными нефтяными концернами, имеющими подразделения в различных федеральных округах. Краткие сведения о ключевых российских компаниях по производству моторных масел, основанные на сообщениях агентства Russian Automobile Market Research [31], представлены в табл. 4.

Ассортимент полиальфаолефиновых масел, выпускаемый отечественными производителями, представлен на рынке следующими маслами: ПАОМ-2, ПАОМ-4, ПАОМ-6, ПАОМ-12 и ПАОМ20. В ближайшей перспективе выпуск базовых масел в четырех российских компаниях должен суммарно составить 2580 тыс. тонн, из них: Лукойл 990 тыс. тонн, Роснефть - 995 тыс. тонн, ГПН-СМ 405 тыс. тонн, ТАНЕКО - 190 тыс. тонн [9].

\section{2. Производство смазочных материалов на российском рынке}

В целом производство смазочных материалов в России в 2014 г. увеличилось и составило 3,2 млн тонн, что на $13 \%$ превысило показатели 2011 г. (2,8 млн тонн). Объемы производства смазочных материалов в целом по Российской Федерации в 2011-2014 гг. представлены на рис. 5.

Согласно данным экспертов Росстата, в 2015 в России было произведено 519,8 тыс. тонн мотор-

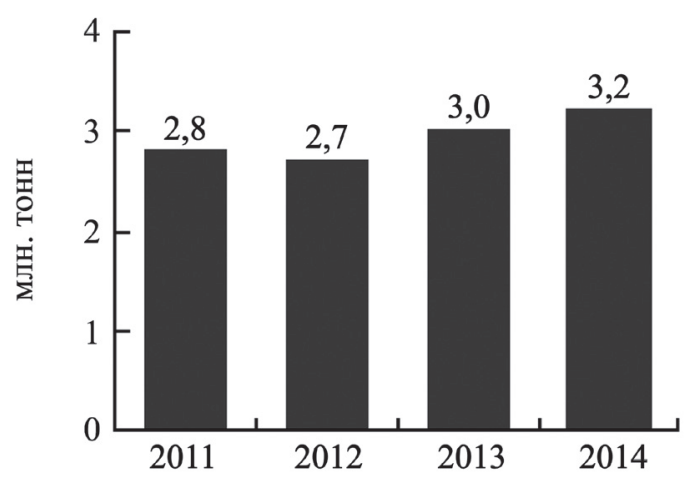

Рис. 5. Производство смазочных материалов в целом по России в 2011 - 2014 гг. [32] 
Основные российские компании по производству моторных масел

Компания $\quad$ Ключевые моменты

\begin{tabular}{|c|c|}
\hline «Роснефть» & $\begin{array}{l}\text { - Моторные масла марок «Революкс», «Магнум Ultratec» и «Роснефть Премиум» } \\
\text { для легкового и грузового транспорта, сельскохозяйственной, строительной } \\
\text { и горнодобывающей техники. } \\
\text { - Присадки к маслам, в частности, экологичная противоизносная присадка } \\
\text { к дизельному топливу Комплексал-ЭКО «Д» (Новокуйбышевский завод масел } \\
\text { и присадок). } \\
\text { - Инвестиционная программа по модернизации производства ключевых } \\
\text { компонентов для автомобильных масел и жидкостей премиального класса. }\end{array}$ \\
\hline $\begin{array}{l}\text { «Газпромнефть - } \\
\text { смазочные материалы» }\end{array}$ & $\begin{array}{l}\text { - Один из лидеров российского рынка (500 тыс. т продукции } \\
\text { в год для обслуживания легковых и грузовых автомобилей российского } \\
\text { и зарубежного производства). } \\
\text { - Новые полностью синтетические моторные масла G-Energy Far East 0W-20 } \\
\text { и 5W-20 для машин японского, корейского и американского производства } \\
\text { (легковые автомобили, внедорожники, легкие грузовики, микроавтобусы). } \\
\text { - Открыт новый современный комплекс по производству масел мощность } \\
180 \text { тыс. т в год в Омске (2014 г.). }\end{array}$ \\
\hline $\begin{array}{l}\text { «ЛЛК-Интернешнл» } \\
\text { («ЛУКОЙЛ») }\end{array}$ & $\begin{array}{l}\text { - Полный ассортимент масел для работы бензиновых и дизельных двигателей } \\
\text { легковых и грузовых автомобилей, автобусов, специальной техники } \\
\text { в различных условиях эксплуатации, который периодически обновляется. } \\
\text { - Расширение новой серии масел «ЛУКОЙЛ Genesis». }\end{array}$ \\
\hline «Delfin Group» & $\begin{array}{l}\text { - Минеральные, синтетические и полусинтетические моторные масла различных } \\
\text { ценовых категорий: масла Spectrol и Highway (выше средней ценовой группы); } \\
\text { масло LUXЕ (средняя ценовая группа); масла Oilright, масла «Ярнефть» и Pilots } \\
\text { (ниже средней ценовой группы). } \\
\text { - Масла марки LUXE соответствуют мировым стандартам, имеют допуски } \\
\text { как мировых (CUMMINS, Mercedes-Benz, MAN), так и российских (KAMA3, } \\
\text { АВTOBA3) производителей двигателей и автомобильной техники. } \\
\text { - Работает с производителями присадок: Infinium, Chevron, Afton и Lubrizol. } \\
\text { - Новое синтетическое моторное масло Spectrol Галакс 5W-30 предназначено } \\
\text { для современных бензиновых или дизельных двигателей с непосредственным } \\
\text { впрыском, наддувом, одной/двумя турбинами. }\end{array}$ \\
\hline «Башнефть» & $\begin{array}{l}\text { - Автомобильные масла различных типов сезонности под брендом Novoil } \\
\text { (Уфимский нефтеперерабатывающий комплекс). } \\
\text { - Ребрендинг всей линейки выпускаемых моторных масел с целью их } \\
\text { продвижения на рынке под единым брендом «Башнефть» в сегменте крупной } \\
\text { фасовки. }\end{array}$ \\
\hline
\end{tabular}

ных масел против 520,6 тыс. тонн в 2014 г. Объем российского рынка в 2016-2017 гг. оценивается в 1,6 млн тонн, что практически соответствует уровню 2015 г., но примерно на 10 \% меньше, чем в 2014 г. (без учета базовых масел, масел-пластификаторов, смазок и смазочно-охлаждающих жидкостей) [33]. Правда, ожидается, что после 2016 года продажи легкового автотранспорта вновь станут расти, что должно положительно сказаться на спросе на смазочные материалы. Так, к 2020 г. их рынок может увеличиться на 12 \% по сравнению 2015 г.
Сравнительные показатели по объемам и темпам роста производства моторных масел на российских предприятиях в период 2010 г. - январьапрель 2016 г. представлены в таблице 5.

В целом российские нефтеперерабатывающие заводы в последнее время выпускают около 2,4 млн тонн минеральных базовых масел I группы в год, 50 \% которых поставляется на экспорт. Основная область применения минеральных базовых масел в России - это отраслевое промышленное производство (порядка 700 тыс. тонн в год), где крупнейшими потребителями являются нефтепе- 
Объемы и темпы производства моторных масел в России в период 2010 г. - апрель 2016 г. в натуральном и стоимостном выражении [34]

\begin{tabular}{lccccccc}
\hline \multicolumn{1}{c}{ Показатель } & $\mathbf{2 0 1 0}$ г. & $\mathbf{2 0 1 1}$ г. & $\mathbf{2 0 1 2}$ г. & $\mathbf{2 0 1 3}$ г. & $\mathbf{2 0 1 4}$ г. & $\mathbf{2 0 1 5}$ г. & $\begin{array}{c}\mathbf{2 0 1 6} \text { г. } \\
\text { янв.-aпр. }\end{array}$ \\
\hline Объем производства, (тыс. т) & 660,4 & 684,1 & 630,8 & 716,4 & 520,6 & 519,8 & 167,5 \\
Темпы роста, (\% в год) & - & 104 & 92 & 114 & 73 & 100 & 110 \\
Объем производства, (млн руб.) & 26,8 & 28,5 & 30,6 & 24,9 & 22,6 & 31,2 & 14,9 \\
Темпы роста, (\% в год) & - & 107 & 107 & 81 & 91 & 138 & 191 \\
\hline
\end{tabular}

рерабатывающая, энергетическая, металлургическая и автомобильная отрасли.

Что касается производства синтетических масел на основе ПАО, то единственным их производителем в России является ООО «Татнефть-НКНХОйл» (Нижнекамсмк), мощность которого составляет 10 тыс. тонн в год [17]. В настоящий момент предприятие испытывает ряд трудностей, из-за которых производство ПАО масел практически остановлено, при том что в нашей стране эксплуатируется около 20 млн автомобилей, из которых более 5 млн приходится на иномарки. Поэтому огромный российский рынок синтетических моторных и других масел с большой выгодой для себя оккупировали зарубежные производители (компании Mobil, Shell, Nesta, Esso, Amoco, Chevron и др.). Эти корпорации сами производят ПАО-масла, а также закупают по низким ценам в России исходное олефиновое сырье и уже на его основе изготавливают внесезонные синтетические ПАО-масла, которые затем экспортируют в Россию на продажу.

Из федеральных округов России наибольший объем выпуска моторных масел приходится на Приволжский федеральный округ (здесь 2016 г. их производство составило $44 \%$ от всего совокупного объема в стране) [34]. На втором месте с долей
24 \% находится Сибирский федеральный округ, на третьем - Центральный федеральный округ с долей $16 \%$.

\section{4. Потребление смазочных материалов в России}

Потребление смазочных материалов всегда зависело от ряда экономических и технологических факторов. Так, события последних лет (продолжающийся мировой экономический кризис, санкции против России, обесценивание рубля, снижение потребительской активности) отрицательно сказались и на рынке смазочных материалов.

На рис. 6 приводятся данные об объемах потребления смазочных материалов в России в период $2011-2014$ гг. [32].

Несмотря на то, что объем потребления смазочных материалов в России, включая базовые масла, в 2014 году составил 2,5 млн тонн, что оказалось на $14 \%$ больше, чем в 2011 году (2,2 млн тонн), тем не менее, за исключением сегмента базовых масел, спрос фактически сократился на $6 \%$ - с 1,6 млн тонн до 1,5 млн тонн. Правда уже после 2016 года ожидается восстановление объема продаж автомобилей, что должно положительно сказаться и на потреблении смазочных материалов. Согласно

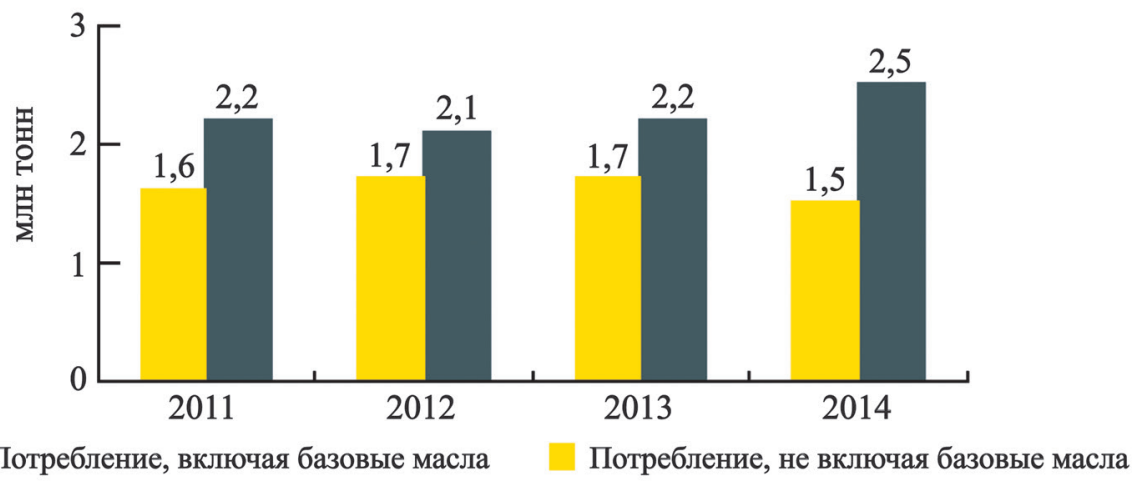

Рис. 6. Объемы потребления смазочных материалов в России в 2011-2014 гг. [32] 
прогнозам, российский рынок автомобильных смазочных материалов должен восстановиться и к 2020 году увеличиться на $12 \%$, что связано с ростом объема продаж легковых автомобилей.

В России $53 \%$ от всех потребляемых смазочных материалов приходится на моторные масла, а 47 \% - на различные виды смазочных масел, применяемых в промышленном производстве, более трети из которых (37 \%) предназначены для гидравлических систем. Общий объем потребления пластичных смазок в России в 2014 г. составил 57 тыс. тонн. Промышленный сектор потребляет около 700 тыс. тонн смазочных материалов в год. Крупнейшими потребителями являются горнодобывающая, нефтеперерабатывающая, энергетическая, металлургическая и автомобильная отрасли, на которые приходится 79 \% от общего объема промышленного потребления.

Из общего объема потребляемых смазочных материалов около 280 тыс. тонн приходится на моторные масла легкового сегмента, ежегодный рост которого обычно не превышает $2 \%$. Около 650 тыс. тонн приходятся на коммерческий сегмент (общественный транспорт, судовые масла, железнодорожные нужды и пр.), а порядка 600 тыс. тонн на индустриально-промышленный сегмент.

\section{5. Российский импорт/экспорт смазочных материалов}

Главным трендом отечественного рынка моторных масел в наши дни эксперты называют снижение объемов импорта. В рамках импортозамещения российские производители смазочных материалов активно инвестируют и проводят модернизацию своих производственных мощностей. При этом, наращивая объемы закупок импортных присадок к маслам, отечественные предприятия одновременно пытаются постепенно вытеснить с рынка потребление импортных синтетических моторных масел.

Импорт. Согласно данным [32], в 2014 году импорт смазочных материалов в Россию сократился на $2 \%$ и составил 547 тыс. тонн, что объясняется обесценением рубля на фоне падения цен на нефть и ростом стоимости импортных смазочных материалов. Цены на моторное масло зарубежных брендов в России с августа 2014 года по август 2015 года выросли в среднем на $31 \%$, а на аналогичную отечественную продукцию - на 8 \%. В 2014 г. поставки импортных моторных масел в Россию составили около 400 тыс. тонн (преимущественно, из Европы). В 2015-2016 гг. объем импорта составил 250-300 тыс. тонн. Вплоть до 2018 года импорт продолжил сокращаться, и вполне возможно, что его ежегодный объем не будет превышать 100 150 тыс. тонн в год. Согласно другим прогнозам, до 2025 года объем импорта останется на уровне 250-350 тыс. тонн в год.

В сегменте легковых автомобилей на долю моторных масел для бензиновых двигателей приходится до 70 \% продаж, из которых $75 \%$ составляет импортная продукция. При этом 50 \% продаж в легковом сегменте занимают синтетические масла.

Эксперты признают, что импортозамещение в сфере смазочных материалов, начавшееся еще в середине 2000-х годов, привело к тому, что российские производители моторных масел сегодня начали производить продукцию, ничем не уступающую по качеству ведущим мировым брендам. При этом рост цен на отечественные моторные масла в 2015 году составил $8 \%$, тогда как импортные масла подорожали на $31 \%$.

В основном смазочные материалы импортируются в Российскую Федерацию из стран ЕС, а объемы импорта из США и стран АТР незначительны. Из стран-импортеров смазочных материалов в Россию отметим Финляндию (четверть от общего объема импорта в нашу страну), Германию, Южную Корею, Бельгию, Белоруссию и др. На фоне действующих сейчас экономических санкций западных стран против нашей страны Правительство Российской Федерации активно стимулирует импортозамещение.

Экспорт. Экономический спад на основных рынках в 2014 г. привел к сокращению и объемов российского экспорта, в связи с чем доля экспорта во внутреннем производстве снизилась на $10 \%$, а объем запасов увеличился вдвое. В основном Россия экспортирует базовые масла, которые перерабатываются за рубежом и затем уже импортируются обратно в нашу страну в виде конечного продукта.

Крупнейшими экспортерами отечественных смазочных материалов являются ПАО «Лукойл», $\mathrm{OAO}$ «НК «Роснефть» и ПАО «Газпромнефть». Основными рынками для российского экспорта смазочных материалов являются Европа и Украина. Если доля поставок в страны ЕС в 2012 г. составляла 50 \%, то в 2014 г. она снизилась до $37 \%$. Для восстановления спроса на российскую продукцию в странах ЕС и СНГ российские производители стараются выйти на новые рынки. Так, например, в последнее время наша страна значительно увеличила экспортные поставки различных смазочных материалов в Китай и Турцию.

Сравнительные показатели объемов российского экспорта/импорта в период 2011-2014 гг. приводятся на рис. 7. 


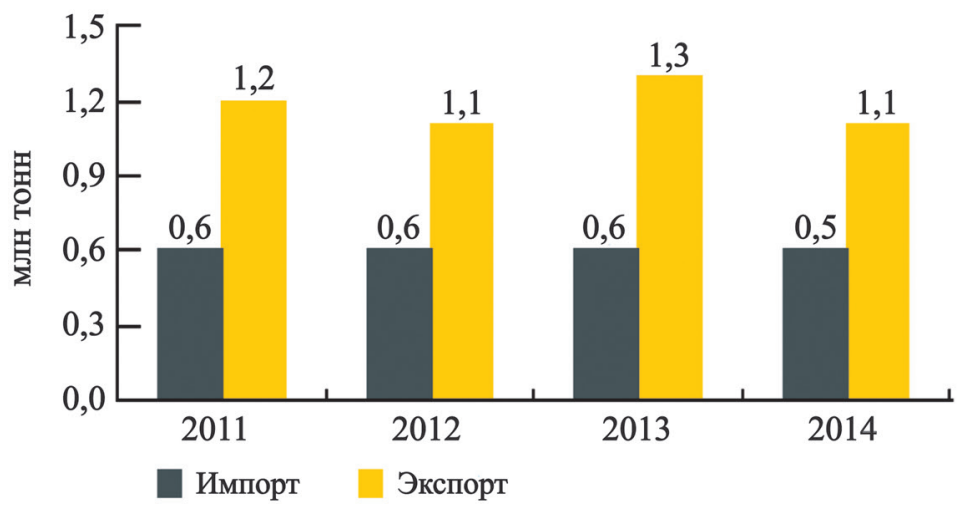

Рис. 7. Объемы российского импорта/экспорта смазочных материалов в 2011-2014 гг. [32]

\section{6. Прогноз развития рынка моторных масел в России}

Представители отечественного рынка моторных масел в целом достаточно позитивно оценивают перспективы его развития, однако в настоящее время рынок характеризуется снижением, что обусловлено экономическим кризисом. Сказался также и прирост продаж иномарок российской сборки, среди которых доминируют легковые автомобили с повышенными требованиями к экономичному расходу топлив и масел.

Сейчас положение на рынке таково, что собственное производство масел в России вместе с импортом превосходит их потребление, поэтому излишки отгружаются на экспорт. С учетом глобального тренда в сторону применения более совершенных и экономичных масел с увеличенным интервалом замены вполне закономерно по итогам 2016 года выглядит снижение потребления масел на 2-3\% на отечественном рынке моторных масел. Подобная тенденция прослеживается не только на нашем рынке, но и на большинстве рынков развитых стран.

В 2015-2016 гг. объем импорта моторных масел в Россию сильно уменьшился и составил всего 250-300 тыс. тонн против 400 тыс. тонн в 2014 г. Эксперты компании «Газпромнефть - смазочные материалы» прогнозируют, что вплоть до 2018 года импорт в стране продолжит сокращаться, и вполне возможно, что его ежегодный объем не превысит 100-150 тыс. тонн в год. Согласно другим прогнозам, до 2025 года объем импорта останется на уровне 250-350 тыс. тонн в год. Это связывают с тем, что на долю иностранных транспортных средств приходится порядка 53 \% отечественного автопарка, поэтому будет наблюдаться спрос на импортные синтетические масла.

По оценкам экспертов, российский рынок смазочных масел в целом в ближайшее время со- хранит звание крупнейшего рынка Европы с долей в $19 \%$. В европейском рейтинге за ним следует Германия с 15-процентной долей. Ожидается, что в России спрос на масла будет расти. Увеличение спроса оценивается аналитиками компании Oliver Wyman в размере 8 \% к 2020 году (до 1,84 млн тонн). Что касается конкретно моторного масла, спрос на него также будет расти (прогнозируется прирост на 5-10 \%) благодаря росту автопарка страны. В ближайшие годы доли моторного масла иностранных и отечественных производителей могут даже уравняться.

Полагают, что дальнейшее развитие российского рынка моторных масел будет определяться ростом спроса на высокотехнологичные масла. При этом доля продаж масел, выпускаемых отечественными предприятиями, будет расти, так как в соответствие с потребностями рынка ведущие российские продуценты наладят их производство на высокотехнологичном уровне. Более того, сегодня амбиции отечественных производителей моторных масел не ограничиваются одной лишь Россией. Отмечают [33], за последние годы такие лидеры российского рынка, как ЛУКОЙЛ и Газпромнефть, существенно расширили свою экспансию на зарубежные рынки. Кроме того, несмотря на то, что сегмент конвейерной заливки на отечественном рынке занимает весьма скромную долю (примерно 3 \% от всего объема реализуемых в стране моторных масел), указанные выше российские компании подписали контракты на поставку своих масел для сборочных и сервисных предприятий ряда известных европейских и китайских автопроизводителей.

\section{Заключение}

Разработка современных смазочных масел и их правильное использование имеют большое значение для экономики любой страны, в том чис- 
ле и России. Оптимально подобранные для решения каждой конкретной задачи, они могут обеспечить миллиардную долларовую экономию в промышленно развитых странах благодаря экономии энергии, снижению износа, уменьшению затрат на техническое обслуживание и удлинение сроков межремонтной эксплуатации машин и оборудования. Расчеты подтверждают, что использование эффективных смазочных материалов и режимов смазки позволяет снизить общие энергетические затраты на 4,5\%.

Синтетические базовые масла, в частности, полиальфаолефиновые масла, обладают целым рядом конкурентных преимуществ по сравнению с минеральными или гидрированными базовыми маслами, однако затраты на сырье и их производство пока еще во много раз выше, чем при производстве традиционных нефтяных масел. Поэтому развитие новых высокоэффективных технологий получения моторных масел нового поколения представляется актуальной задачей мирового уровня, для решения которой требуются весьма внушительные инвестиции в научно-исследовательские, инжиниринговые и промышленные работы.

Работа выполнена в рамках Государственного задания № 0089-2019-0018 по теме: «Разработка научных основ комплексных энергоэффективных методов глубокой переработки углеводородных ресурсов с получением ценных химических продуктов».

\section{Лuтература}

1. Conventional vs Synthetic Oil. URL: https://web.archive.org/web/20100406025206/http:/www.machinerylubrication.com/Read/23715/conventional-vs-synthetic-oil (дата обращения: 17.05.2019).

2. Lubricants Market Worth 166.59 Billion USD by 2021. URL: http://www.prnewswire.co.uk/newsreleases/lubricants-market-worth-16659-billionusd-by-2021-571031801.html (дата обращения: 17.05.2019).

3. Манг T. Обзор рынка смазочных материалов. Эксперт-Ойл. URL: http://www.expert-oil.com/articles/articles_52.html (дата обращения: 17.05.2019).

4. Базовые присадки к смазочным материалам. URL: http://www.auto-uch.info/a_pr_02.html (дата обращения: 17.05.2019).

5. Базовые масла для производства моторных масел. URL: https://www.autoshcool.ru/1785-bazovyemasla-dlya-proizvodstva-motornyx-masel.html (дата обращения: 17.05.2019).

6. Маркетинговое исследование рынка моторных масел в России 2011-2015 гг. Прогноз до 2020г. ГидМаркет. URL: https://gidmark.ru/uploads/raboty/december2016/rynok-motornyh-masel-demo.pdf (дата обращения: 17.05.2019).
7. Brawn S.F. Base Oil Groups: Manufacture, Properties and Performance. Internet Conference STLE Webinar on base oils. October 8, 2014. URL: https://www.stle.org/ images/pdf/STLE_ORG/BOK/OM_OA/Base\%20Oils/ Base\%20Oil\%20Groups_Manufactore_Prop_Perform_ April15\%20TLT.pdf (дата обращения: 17.05.2019).

8. Технологии, используемые при производстве масел, полиальфаолефины, диэфиры. URL: http://www.avtomarketkar-go.ru/info/technologies (дата обращения: 17.05.2019).

9. Цветков О.Н. Перспективные направления развития масловедения в России (Международная академия холода). Круглый стол по проблемам производства и применения смазочных материалов. ИНХС РАН, 8 декабря 2017г.

10. Выбираем моторное масло: Синтетическое или... синтетическое? URL: https://www.autodela.ru/main/ top/review/sintech_oill (дата обращения: 17.05.2019).

11. Gee J.C., Small B.L., Hope K.D. J. Phys. Org. Chem. 2012. V. 25. P. $1409-1417$.

12. Huang $Q$., Chen L., Ma L., Fu Z., Yang $W$. Eur. Polym. J. 2005. V. 41. P. 2909-2915.

13. Synthetic Lubricants Market - Global Analysis, Current Trends, Forecast to 2020. URL: https://www.mordorintelligence.com/industry-reports/synthetic-lubricantsmarket... (дата обращения: 17.05.2019).

14. Матковский П.Е, Стариева Г.П., Алдошин С.М., Троичкий В.Н., Чуркина В.Я., Бойко Г.Н., Кнерельман Е.И., Давыдова Г.И., Баймамова Г.М., Васильева Л.П., Кузаев А.И., Демидов М.А., Шамсутдинов В.Г., Ильясов Г.Л., Михайлович Дж., Иотанович К. ВМС. Серия А. 2003. Т. 45. № 12. С. 1993 - 2009.

15. Huang $Q$., Chen L., Sheng Y., Ma L., Fu Z., Yang W. J. Appl. Polym. Sci. 2006. V. 101. P. 84-590.

16. Patent US 4,827,064 (publ. 1989). High viscosity index synthetic lubricant compositions.

17. Матковский П.Е., Алдошин С.М., Савченко В.И., Троиикий В.Н., Демидов М.А., Шамсутдинов В.Г., Яруллин Р.С. Разработка и промышленная реализация процесса получения синтетических олиголеценовых масел (Монография). ISBN: 5-901675-47-9. Черноголовка: Изд-во ИПХФ РАН. 2004.121 с.

18. А.С. СССР 1723101 А1 (опубл. 1989 г.). Способ получения основы синтетического смазочного масла.

19. Patent US 9,234,150 (publ. 2016). Low viscosity engine oil compositions.

20. Köhn R.D., Haufe M., Kociok- Köhn G., Grimm S., Wasserscheid P., Keim W. Angew. Chem. Int. Ed. 2000. V. 39. P. 4337-4339.

21. Sattler A., Labinger J.A., Bercaw J.E. Organometallics. 2013. V. 32. P. 6899-6902.

22. Patent US 8,889,931 (publ. 2014). Processes for preparing low viscosity lubricating oil base stocks.

23. Janiak C. Coord. Chem. Rev. 2006. V. 250. P. 66-94.

24. Kaminsky W. Macromol. Symp. 1995. V. 89. P. 203-219.

25. Janiak C., Lange K.C.H., Marquardt P. Macromol. Rapid Commun. 1995. V. 16. P. 643-650.

26. Nifant'ev I.A., Vinogradov A.A., Vinogradov A.A., Sedov I.V., Dorokhov V.G., Lyadov A.S., Ivchenko P.V. Applied Catalysis A, General. 2018. V. 549. P. 40-50. 
27. Oil demand and supply forecasts. URL: http://www.lubricants.total.com/news/oil-demand-and-supply-forecasts.html (дата обращения: 17.05.2019).

28. Synthetic Lubricants Market by Type (PAO, Esters, Group III, PAG), by Application (Engine Oil, Metalworking Fluids, and Industrial) and by Regions (Europe, North America, Asia-Pacific and Rest of the World) - Global Trends \& Forecasts to 2020. URL: http://www.marketsandmarkets.com/Market-Reports/synthetic-lubricantmarket-141429702.html (дата обращения: 17.05.2019).

29. Synthetic Lubricants Market Worth 36.0 Billon USD by 2020. Jan. 06, 2016. URL: https://www.prnewswire.com/news-releases/synthetic-lubricants-marketworth-360-billion-usd-by-2020-564351941.html (дата обращения: 17.05.2019).

30. US Industry Study with Forecast for 2018 \& 2023. URL: https:/www.freedoniagroup.com/ brochure/31xx/3188smwe.pdf (дата обращения: 17.05.2019).
31. Рынок автомобильных масел в России. URL: http:// www.napinfo.ru/articles/rynok-avtomobilnyrh-maselv-rossii (дата обращения: 17.05.2019).

32. Обзор российского рынка смазочных материалов 2015 год. URL: http://www.ey.com/publications/vwLUAssets/EY-russian-lubricants... (дата обращения: 17.05.2019).

33. Российский рынок моторных масел: счастье не в объеме, а в его качестве. URL: https://allpetro. ru/rossijskij-rynok-motornyh-masel-schaste-ne-vobeme...

34. Колтыкова E. Рынок моторных масел в России нестабилен. URL: https://www.indexbox.ru/news/Proisvodstvo-motornyh-masel-v-Rossii-nestabilno/ (дата обращения: 17.05.2019).

35. Григорьева О. Куда «скользит» рынок масел и смазок. URL: http://ogjrussia.com/uploads/images/Atricles/August\%2016/100-103_Perer3.pdf (дата обращения: 17.05.2019). 